\title{
Comparison of Toxin Composition Between Populations of Alexandrium spp. from Geographically Distant Areas
}

\author{
Chang-Hoon Kim, ${ }^{* 1,2}$ Yoshihiko Sako, ${ }^{* 1,3}$ and Yuzaburo Ishida*1 \\ (Received June 15, 1992)
}

\begin{abstract}
Axenic clonal isolates of the dinoflagellates Alexandrium tamarense and $A$. catenella derived from benthic cysts from Ofunato Bay (Iwate Prefecture, Japan), Tanabe Bay (Wakayama Prefecture, Japan) and motile cells from the Seto Inland Sea were subjected to toxin analysis by HPLC. Toxin contents and compositions of two or four sexually different vegetative cell germinated from each cyst were compared. In $A$. tamarense, the toxin compositions (mole $\%$ ) of six isolates were relatively constant, but one isolate showed a clear distinction in a lack of $N$-sulfocarbamoyl (Cx) toxins. In $A$. catenella, the toxin composition was rather uniform within a geographical region. Moreover, toxin compositions of $A$. catenella isolates from Tanabe Bay and the Seto Inland Sea were clearly distinguished from those of $A$. catenella from Ofunato Bay. These results indicate the occurence of inter-and intra-specific indigenous populations from distant localities, and the toxin profiles separate one morphospecies into two regional populations.
\end{abstract}

Several dinoflagellates of the genus Alexandrium produce potent neurotoxins responsible for paralytic shellfish poisoning (PSP). Toxicity of an array of those toxins varies by several orders of magnitude. ${ }^{1)}$ The northeastern coast of Japan, especially Ofunato Bay, is a representative area for PSP problems; the occurrence of Alexandrium spp. and shellfish infestation have been well documented. ${ }^{2-\theta)}$ Oshima et al. ${ }^{7)}$ investigated the toxin profiles of $A$. tamarense from various locations of northern districts. The toxin profile revealed a similar pattern within a geographical region, but this is not the case in different regions. The same trend was observed in the isolates from North America ${ }^{8-10)}$ and from widely separated geographical locations (the northeastern Pacific, eastern Canada, Portugal, the United Kingdom, and New Zealand). ${ }^{11}$ ) However, toxin composition changes in an isolate occur under different growth conditions. ${ }^{11}$ ) Toxin profile varied among the unaxenic isolates of $A$. tamarense or $A$. catenella from different regions, and it was not significantly related to morphological differences. ${ }^{11,12)}$

In the present study, axenic clonal isolates of $A$. tamarense and $A$. catenella established from benthic cysts in Ofunato Bay (Iwate Prefecture) and Tanabe Bay (Wakayama Prefecture), and vegetative cells isolated from the Seto Inland Sea were subjected to toxin analysis by HPLC. Toxin compositions among geographiccally different populations of Alexandrium were compared.

\section{Materials and Methods}

\section{Organisms and Culture}

Cysts of the genus Alexandrium were isolated from sediments in Ofunato Bay (Iwate Prefecture, Japan, 1984 and 1988), and Tanabe Bay (Wakayama Prefecture, Japan, 1987). Individual cysts were isolated and germinated in SWIIm medium at $20^{\circ} \mathrm{C}$. The germinant cells through the first and second cell divisions were separated individually and grown enough to obtain axenic clones by a micropipette washing method. After preparing axenic culture, mating type was determined by crossing these clones with each other. Three strains (SE6, SE7, SE82) of $A$. catenella were kindly provided by Dr. S. Yoshimatsu (Akashiwo Research Institute of Kagawa Prefecture), which were isolated from a water sample from the Seto

Abbreviation: PSP, paralytic shellfish poisoning; GTX, gonyautoxin; STX, saxitoxin; NEO, neosaxitoxin.

*1 Laboratory of Microbiology, Department of Fisheries, Faculty of Agriculture, Kyoto University, Kita-

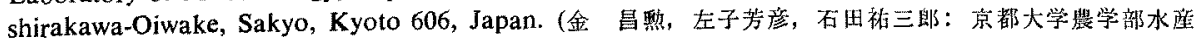
微生物学研究室)。

*2 Present address: Department of Fisheries Biology, National Fisheries University of Pusan, Pusan 608 737, Korea

*3 To whom reprint requests should be sent. 
Table 1. Origin of Alexandrium tamarense and A. catenella isolates germinated from benthic cysts from Ofunato Bay and Tanabe Bay

\begin{tabular}{|c|c|c|c|c|}
\hline Isolates & Origin & $\begin{array}{c}\text { Date of } \\
\text { sampling/isolation }\end{array}$ & $\begin{array}{c}\text { Mating } \\
\text { type }\end{array}$ & $\begin{array}{c}\text { Type of } \\
\text { parent cell }\end{array}$ \\
\hline \multicolumn{5}{|c|}{ A. tamarense } \\
\hline OF151 & $\begin{array}{l}\text { Ofunato Bay, Iwate } \\
\left(141^{\circ} 43^{\prime} \mathrm{E}-39^{\circ} 2^{\prime} \mathrm{N}\right)\end{array}$ & Mar 1984/1988 & + & $\mathbf{T}(\mathrm{C})$ \\
\hline OF 152 & $"$ & $"$ & - & $\mathrm{T}(\mathrm{C})$ \\
\hline OF181 & $"$ & $"$ & + & $T(C)$ \\
\hline OF184 & $"$ ". & " & - & $T(C)$ \\
\hline OF191 & " & $"$ & + & $T(C)$ \\
\hline OF192 & $"$ & $"$ & - & $T(C)$ \\
\hline OF051 & " & $"$ & + & $\mathrm{T}(\mathrm{C})$ \\
\hline \multicolumn{5}{|l|}{ A. catenella } \\
\hline OF071 & $\begin{array}{l}\text { Ofunato Bay, Iwate } \\
\left(141^{\circ} 43^{\prime} \mathrm{E}-39^{\circ} 2^{\prime} \mathrm{N}\right)\end{array}$ & Mar 1988/1988 & - & $T(C)$ \\
\hline OF072 & " & " & + & $T(C)$ \\
\hline OF101 & $"$ & $"$ & - & $T(C)$ \\
\hline OF102 & $"$ & " & + & $\mathrm{T}(\mathrm{C})$ \\
\hline TN7 & $\begin{array}{c}\text { Tanabe Bay, Wakayama } \\
\left(135^{\circ} 22^{\prime} \mathrm{E}-33^{\circ} 41^{\prime} \mathrm{N}\right)\end{array}$ & May $1987 / 1987$ & - & $T(C)$ \\
\hline TN9 & $"$ & $"$ & + & $T(C)$ \\
\hline TN10 & $"$ & $"$ & - & $T(C)$ \\
\hline TN11 & $"$ & $"$ & - & $\mathrm{T}(\mathrm{C})$ \\
\hline TN12 & " & " & + & $T(C)$ \\
\hline TN16 & " & $"$ & - & $T(C)$ \\
\hline $\mathrm{TN} 22$ & $"$ & $"$ & + & $\mathrm{T}(\mathrm{C})$ \\
\hline SE6 & Harima Nada, Kagawa & 1981 & - & $\mathbf{M}$ \\
\hline SE7 & $"$ & $"$ & & M \\
\hline SE82 & $"$ & $"$ & + & M \\
\hline
\end{tabular}

Motile cells from Harima Nada of the Seto Inland Sea were adopted for comparing.

$T(C)$, one of the tetrad cells divided from a germinated cyst; $M$, motile cell isolated from water sample.

Inland Sea in 1980. Axenic cultures were established by us. Details of origin are presented in Table 1. All cultures were maintained in SWIIm medium at $15^{\circ} \mathrm{C}$ for $A$. tamarense and at $20^{\circ} \mathrm{C}$ for A. catenella. ${ }^{13)}$

Cultures for toxin analyses used in this experiment were grown at 15 or $20^{\circ} \mathrm{C}$ with $14 \mathrm{~L}$ : $10 \mathrm{D}$ cycle at $100 \mu \mathrm{Em}^{-2} \mathrm{~s}^{-1}$ with cool white bulbs. ${ }^{132}$ Approximately $10^{6}$ cells at the mid-exponential growth phase were inoculated in $2 l$ of SWIIm medium contained in a $3 l$ flask. Cells (ca. $2 \times$ $10^{5}$ ) were harvested in the mid-exponential growth stage at the mid-point of the light phase in the photocycle, in which toxin content and toxin composition were stable, as established in the previous study. ${ }^{13,11}$ )

\section{Toxin analysis}

The sampled cells were concentrated by centrifugation $(2,000 \mathrm{~g} \times 5 \mathrm{~min})$ at $20^{\circ} \mathrm{C}$. The cells were rinsed once with cold distilled water and recentrifuged. The pelleted cells were resuspended in $0.05 \mathrm{M}$ acetic acid and were stored at $-20^{\circ} \mathrm{C}$ until toxins were extracted. The frozen samples were thawed and disrupted by mild sonication at $0^{\circ} \mathrm{C}$. After the sonication the cell debris was removed by centrifugation $(10,000 \mathrm{~g} \times 10 \mathrm{~min})$. The supernatant was filtered through a membrane filter with $10,000 \mathrm{MW}$ cut-off (Ultrafree C3GC, Millipore) by centrifugation $(8,000 \mathrm{~g} \times 5 \mathrm{~min})$, and stored at $-20^{\circ} \mathrm{C}$, until analysis. ${ }^{14}$ Toxin analyses were carried out by means of an HPLC-fluorometric PSP toxin analyser (Waters $600 \mathrm{E}$ system, 470 fluoromonitor) on Wakosil $5 \mathrm{C} 8$ column ( $4.6 \times$ $250 \mathrm{~mm}$; Wako Pure Chemical) as described by Oshima et al. ${ }^{14}$

\section{Results and Discussion}

Table 1 shows a list of the isolates examined. All isolates were identified as $A$. tamarense or $A$. catenella on the basis of morphological taxonomy 
Table 2. Individual toxin content per cell and percent composition of total toxin from Alexandrium tamarense and $A$. catenella analysed by HPLC

\begin{tabular}{|c|c|c|c|c|c|c|c|c|c|c|c|c|c|c|c|}
\hline \multirow{2}{*}{ Isolates } & \multirow{2}{*}{ Sexuality } & \multicolumn{14}{|c|}{ Toxins, fmol/cell ( $\%$ composition of total toxin) } \\
\hline & & GTX1 & GTX2 & GTX3 & GTX4 & dcGTX3 & GTX5 & GTX6 & epiGTX8 & GTX8 & $\mathrm{C} 4$ & neosTX & deSTX & STX & Total \\
\hline OF151 & + & $\begin{array}{c}1.0 \\
(2.0)\end{array}$ & - & $\begin{array}{c}0.6 \\
(1.1)\end{array}$ & $\begin{array}{c}13.8 \\
(26.5)\end{array}$ & - & - & - & $\begin{array}{c}0.7 \\
(1.4)\end{array}$ & $\begin{array}{c}35.4 \\
(67.8)\end{array}$ & $\begin{array}{c}0.6 \\
(1.1)\end{array}$ & $\operatorname{Tr}$ & - & - & $\begin{array}{l}52.2 \\
(100)\end{array}$ \\
\hline OF 152 & - & $\begin{array}{r}4.2 \\
(13.6)\end{array}$ & $\begin{array}{c}0.1 \\
(0.3)\end{array}$ & $\begin{array}{c}0.9 \\
(2.9)\end{array}$ & $\begin{array}{c}25.2 \\
(80.5)\end{array}$ & - & - & - & - & - & - & $\begin{array}{c}0.9 \\
(2.7)\end{array}$ & $\operatorname{Tr}$ & $\operatorname{Tr}$ & $\begin{array}{l}31.3 \\
(100)\end{array}$ \\
\hline OF181 & + & $\begin{array}{l}1.0 \\
(2.7)\end{array}$ & $\begin{array}{c}0.2 \\
(0.4)\end{array}$ & $\begin{array}{l}1.5 \\
(4.1)\end{array}$ & $\begin{array}{r}7.9 \\
(21.0)\end{array}$ & - & - & - & $\begin{array}{c}0.7 \\
(1.9)\end{array}$ & $\begin{array}{c}25.9 \\
(69.1)\end{array}$ & - & $\mathrm{Tr}$ & $\begin{array}{c}0.3 \\
(0.7)\end{array}$ & - & $\begin{array}{l}37.4 \\
(100)\end{array}$ \\
\hline OF184 & - & $\begin{array}{l}1.8 \\
(7.8)\end{array}$ & - & $\begin{array}{c}0.5 \\
(2.1)\end{array}$ & $\begin{array}{r}5.6 \\
(23.9)\end{array}$ & - & - & - & $\begin{array}{c}0.7 \\
(3.2)\end{array}$ & $\begin{array}{r}11.9 \\
(50.4)\end{array}$ & $\begin{array}{c}0.2 \\
(0.7)\end{array}$ & $\begin{array}{c}2.1 \\
(8.8)\end{array}$ & $\begin{array}{c}0.7 \\
(3.1)\end{array}$ & - & $\begin{array}{l}23.5 \\
(100)\end{array}$ \\
\hline OF191 & + & $\begin{array}{c}0.6 \\
(0.9)\end{array}$ & $\mathrm{Tr}$ & $\begin{array}{c}0.2 \\
(0.3)\end{array}$ & $\begin{array}{r}6.7 \\
(11.0)\end{array}$ & $\operatorname{Tr}$ & - & - & $\begin{array}{l}0.8 \\
(1.4)\end{array}$ & & $\begin{array}{c}0.9 \\
(1.5)\end{array}$ & $\begin{array}{r}16.9 \\
(27.6)\end{array}$ & - & $\begin{array}{c}2.0 \\
(3.2)\end{array}$ & $\begin{array}{l}61.1 \\
(100)\end{array}$ \\
\hline OF192 & - & $\begin{array}{l}0.6 \\
(1.3)\end{array}$ & $\begin{array}{c}0.1 \\
(0.1)\end{array}$ & $\begin{array}{l}0.2 \\
(0.5)\end{array}$ & $\begin{array}{r}5.8 \\
(12.1)\end{array}$ & - & - & - & $\begin{array}{l}0.7 \\
(1.5)\end{array}$ & $\begin{array}{r}29.5 \\
(62.1)\end{array}$ & $\begin{array}{c}0.4 \\
(0.8)\end{array}$ & $\begin{array}{l}10.3 \\
(21.6)\end{array}$ & - & $\mathrm{Tr}$ & $\begin{array}{l}47.6 \\
(100)\end{array}$ \\
\hline OF051 & + & $\begin{array}{c}1.0 \\
(1.8) \\
\end{array}$ & - & $\begin{array}{r}0.6 \\
(1.2) \\
\end{array}$ & $\begin{array}{r}16.2 \\
(30.1) \\
\end{array}$ & - & - & - & $\begin{array}{r}0.6 \\
(1.2) \\
\end{array}$ & $\begin{array}{r}26.4 \\
(49.0) \\
\end{array}$ & $\begin{array}{l}1.0 \\
(1.8) \\
\end{array}$ & $\begin{array}{r}8.2 \\
(15.1) \\
\end{array}$ & - & $\operatorname{Tr}$ & $\begin{array}{l}53.9 \\
(100) \\
\end{array}$ \\
\hline OF071 & - & - & - & $\begin{array}{c}0.0 \\
(0.1)\end{array}$ & - & - & $\begin{array}{c}0.7 \\
(1.4)\end{array}$ & - & $\begin{array}{c}0.4 \\
(0.8)\end{array}$ & $\begin{array}{c}13.3 \\
(28.1)\end{array}$ & $\begin{array}{c}0.1 \\
(0.2)\end{array}$ & $\begin{array}{r}31.9 \\
(67.5)\end{array}$ & - & $\begin{array}{c}0.9 \\
(2.0)\end{array}$ & $\begin{array}{l}47.3 \\
(100)\end{array}$ \\
\hline OF072 & + & - & - & $\begin{array}{l}0.1 \\
(0.4)\end{array}$ & - & - & $\begin{array}{c}0.3 \\
(1.4)\end{array}$ & $\cdots$ & $\begin{array}{r}0.3 \\
(1.4)\end{array}$ & $\begin{array}{r}6.9 \\
(33.2)\end{array}$ & - & $\begin{array}{l}10.4 \\
(50.0)\end{array}$ & - & $\begin{array}{r}2.8 \\
(13.5)\end{array}$ & $\begin{array}{l}20.7 \\
(100)\end{array}$ \\
\hline OF101 & - & - & - & $\begin{array}{c}0.1 \\
(0.4)\end{array}$ & $\operatorname{Tr}$ & - & Tr & - & 13 & $\begin{array}{l}14.1 \\
(57.6)\end{array}$ & - & $\begin{array}{r}7.5 \\
(30.6)\end{array}$ & - & 1.5 & 24.5 \\
\hline OF 102 & + & - & - & $\begin{array}{c}0.6 \\
(0.9) \\
\end{array}$ & - & - & $\begin{array}{c}0.2 \\
(0.4) \\
\end{array}$ & - & $\begin{array}{c}0.3 \\
(0.6) \\
\end{array}$ & $\begin{array}{r}9.0) \\
(15.9) \\
\end{array}$ & - & $\begin{array}{c}(30.0) \\
46.5 \\
(79.4) \\
\end{array}$ & - & $\begin{array}{c}(0.1) \\
1.6 \\
(2.8) \\
\end{array}$ & $\begin{array}{l}(100) \\
58.5 \\
(100) \\
\end{array}$ \\
\hline TN7 & - & $\begin{array}{c}0.2 \\
(0.5)\end{array}$ & - & $\begin{array}{c}0.0 \\
(0.1)\end{array}$ & $\begin{array}{r}2.2 \\
(5.9)\end{array}$ & - & $\begin{array}{c}13.5 \\
(35.7)\end{array}$ & $\begin{array}{c}0.2 \\
(0.5)\end{array}$ & $\begin{array}{c}0.5 \\
(1.4)\end{array}$ & $\begin{array}{c}19.0 \\
(50.2)\end{array}$ & $\begin{array}{c}1.1 \\
(2.9)\end{array}$ & $\mathrm{Tr}$ & $\operatorname{Tr}$ & $\begin{array}{c}1.0 \\
(2.8)\end{array}$ & $\begin{array}{l}37.8 \\
(100)\end{array}$ \\
\hline TN9 & + & $\begin{array}{r}0.3 \\
(1.5)\end{array}$ & - & $\begin{array}{c}0.1 \\
(0.3)\end{array}$ & $\begin{array}{r}0.9 \\
(5.2)\end{array}$ & - & $\begin{array}{r}3.1 \\
(17.8)\end{array}$ & $\begin{array}{r}3.5 \\
(20.0)\end{array}$ & $\begin{array}{c}0.5 \\
(3.1)\end{array}$ & $\begin{array}{r}8.6 \\
(48.9)\end{array}$ & $\begin{array}{c}0.6 \\
(3.1)\end{array}$ & - & - & - & $\begin{array}{l}17.6 \\
(100)\end{array}$ \\
\hline TN10 & - & $\mathrm{Tr}$ & - & $\begin{array}{l}0.0 \\
0.11\end{array}$ & 1.7 & - & $\begin{array}{c}6.1 \\
(18.4)\end{array}$ & 0.2 & 0.4 & 23.7 & 1.3 & - & - & $\operatorname{Tr}$ & 33.5 \\
\hline TN11 & - & $\begin{array}{c}0.2 \\
(1.7)\end{array}$ & - & $\begin{array}{c}0.0 \\
(0.3)\end{array}$ & $\begin{array}{r}1.6 \\
(13.0)\end{array}$ & - & $\begin{array}{c}2.4) \\
2.4 \\
(19.0)\end{array}$ & $\mathrm{Tr}$ & $\begin{array}{c}(1.1) \\
0.2 \\
0.7)\end{array}$ & $\begin{array}{c}(70.9) \\
6.5 \\
(51.7)\end{array}$ & $\begin{array}{r}(3.9) \\
1.3 \\
(10.3)\end{array}$ & $\mathrm{Tr}$ & - & $\begin{array}{c}0.3 \\
(2.3)\end{array}$ & $\begin{array}{l}(100) \\
12.6\end{array}$ \\
\hline TN12 & + & $\operatorname{Tr}$ & - & $\mathrm{Tr}$ & $\begin{array}{c}1.7 \\
(5.5)\end{array}$ & - & $\begin{array}{r}3.1 \\
(9.9)\end{array}$ & $\begin{array}{c}14.8 \\
(48.1)\end{array}$ & $\begin{array}{c}(1.1) \\
0.2 \\
(0.6)\end{array}$ & $\begin{array}{c}(51.7) \\
9.3 \\
(30.4)\end{array}$ & $\begin{array}{c}(10.3) \\
1.1 \\
(3.5)\end{array}$ & - & - & $\begin{array}{c}(2.3) \\
0.6 \\
(2.1)\end{array}$ & $\begin{array}{l}(100) \\
30.7 \\
(100)\end{array}$ \\
\hline TN16 & - & - & - & $\begin{array}{c}0.0 \\
(0.1)\end{array}$ & $\begin{array}{l}1.5 \\
(6.7)\end{array}$ & $\begin{array}{c}0.0 \\
(0.1)\end{array}$ & $\begin{array}{c}1.7 \\
(7.6)\end{array}$ & $\begin{array}{r}9.2 \\
(40.6)\end{array}$ & $\begin{array}{r}0.3 \\
(1.4)\end{array}$ & $\begin{array}{r}8.9 \\
(39.2)\end{array}$ & $\begin{array}{l}1.0 \\
(4.5)\end{array}$ & - & - & - & $\begin{array}{l}22.6 \\
(100)\end{array}$ \\
\hline TN22 & + & Tr & - & $\operatorname{Tr}$ & $\begin{array}{r}2.4 \\
(13.6) \\
\end{array}$ & - & $\begin{array}{r}6.4 \\
(35.5) \\
\end{array}$ & $\begin{array}{r}0.5 \\
(2.9) \\
\end{array}$ & $\begin{array}{r}0.5 \\
(2.9) \\
\end{array}$ & $\begin{array}{r}7.3 \\
(40.5) \\
\end{array}$ & $\begin{array}{c}0.8 \\
(4.5) \\
\end{array}$ & - & - & $\operatorname{Tr}$ & $\begin{array}{l}17.9 \\
(100) \\
\end{array}$ \\
\hline SE6 & + & - & - & $\begin{array}{c}0.0 \\
(0.1)\end{array}$ & $\begin{array}{c}1.0 \\
(3.5)\end{array}$ & - & $\begin{array}{c}5.6 \\
(20.3)\end{array}$ & $\begin{array}{c}3.9 \\
(14.2)\end{array}$ & $\begin{array}{c}0.5 \\
(2.0)\end{array}$ & $\begin{array}{c}15.3 \\
(55.9)\end{array}$ & $\begin{array}{c}1.1 \\
(4.0)\end{array}$ & - & - & - & $\begin{array}{l}27.4 \\
(100)\end{array}$ \\
\hline SE7 & & - & - & $\begin{array}{c}0.0 \\
(0.2)\end{array}$ & $\begin{array}{c}1.2 \\
(4.8)\end{array}$ & - & $\begin{array}{c}5.1 \\
(20.9)\end{array}$ & $\begin{array}{c}0.7 \\
(2.9)\end{array}$ & $\begin{array}{c}0.4 \\
(1.5)\end{array}$ & $\begin{array}{c}10.8 \\
(44.7)\end{array}$ & $\begin{array}{c}0.5 \\
(2.2)\end{array}$ & $\begin{array}{c}5.5 \\
(22.8)\end{array}$ & - & - & $\begin{array}{l}24.2 \\
(100)\end{array}$ \\
\hline SE82 & + & $\operatorname{Tr}$ & - & $\mathrm{Tr}_{T}$ & $\begin{array}{r}0.5 \\
(3.0) \\
\end{array}$ & $-m$ & $\begin{array}{r}0.8 \\
(5.0)\end{array}$ & $\begin{array}{c}5.8 \\
(35.3)\end{array}$ & $\begin{array}{r}0.1 \\
(0.8) \\
\end{array}$ & $\begin{array}{r}7.1 \\
(43.4) \\
\end{array}$ & $\begin{array}{r}0.6 \\
(3.4) \\
\end{array}$ & $\begin{array}{c}1.5 \\
(9.1)\end{array}$ & - & - & $\begin{array}{l}16.4 \\
(100)\end{array}$ \\
\hline
\end{tabular}


described by the criteria of Fukuyo ${ }^{18)}$ and isozyme analysis, ${ }^{17}$ and reactivity of monoclonal antibody. ${ }^{18)}$ Each isolate showed either $(+)$ or $(-)$ mating type in sexuality (Table 1), according to heterothallic characteristics, ${ }^{1 \theta-21}$ ) When toxin content and toxin composition of sexually different isolates germinated from each cyst were compared, distinct similarities of toxin composition were observed in each pair except for one pair of A. tamarense (OF151 and OF152) (Table 2). In A. catenella, about twice the difference in toxin content was observed in four isolates from Ofunato Bay (Table 2). Toxin content of A. tamarense from Ofunato Bay was nearly twice as high than that of A. catenella from Tanabe Bay (Table 2). The differences in toxin content ( $\mathrm{f} \mathrm{mol} / \mathrm{cell}$ ) between isolates from geographically distant regions were also reported by Cembella et al. ${ }^{11}$ As de- cribed by Anderson, ${ }^{22}$ ) northern isolates from Japan largely contain highly potent carbamate toxins (e.g. NEO and GTX1-4), whereas southern isolates largely contain weaker $N$-sulfocarbamoyl toxins (e.g. GTX5, GTX6, GTX8, epiGTX8, and C4) (Table 2).

The previous papers ${ }^{13,14}$, and several investigators, ${ }^{11,23,24)}$ concluded that toxin composition is a stable property under identical growth conditions, and that composition differences have a genetic basis in $A$. tamarense and $A$. catenella. The toxin compositions of seven isolates of $A$. tamarense from Ofunato Bay and four isolates, seven isolates, and three isolates of $A$. catenella from Ofunato Bay, Tanabe Bay, and the Seto Inland Sea, respectively, were compared (Fig. 1). In $A$. tamarense, the toxin composition of six isolates from Ofunato Bay, except for OF152
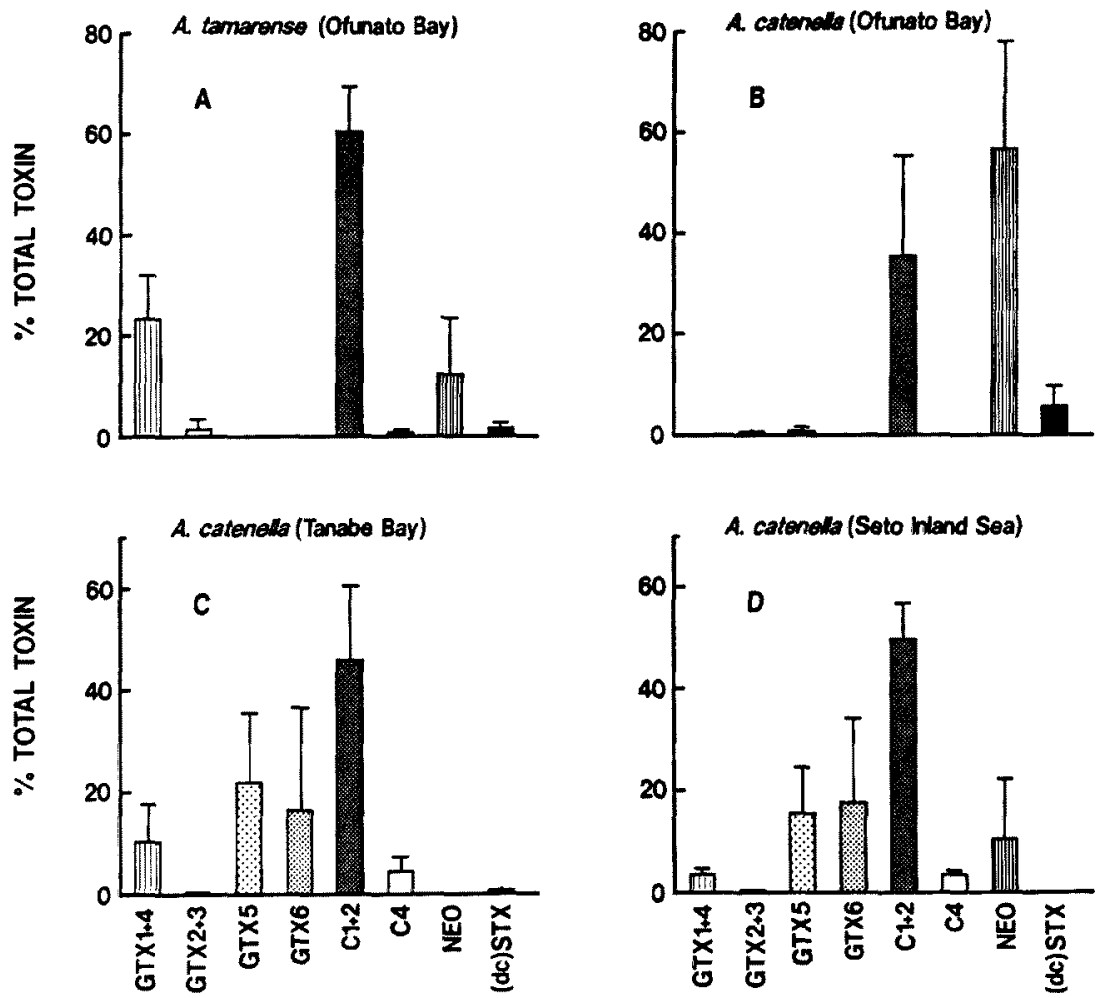

Fig. 1. Comparison of the average toxin composition (as \% total toxin) of $A$. tantarense (A) and A. catenella (B, C, D) collected from different regions.

A, 7 isolates from benthic cysts (Ofunato Bay); B, 4 isolates from benthic cysts (Ofunato Bay); C, 7 isolates from benthic systs (Tanabe Bay); D, 3 isolates from motile cells (Seto Inland Sea). Error bars denote one standard deviation. Abbreviations: $\mathrm{Cl}$, epiGTX 8; C2, GTX 8; NEO, neoSTX; (dc)STX, deSTX+STX. 
which were deficient in $\mathrm{Cx}$ toxins, included GTX8 (49-69 $\mathrm{mol} \%$ and GTX4 (11-30 $\mathrm{mol} \%$ ) as major components, and GTX1, GTX2, GTX3, and NEO (Trace-27 $\mathrm{mol} \%$ ) as minor components, with the sporadic appearance of dcSTX and STX (Table 2).

Sekiguchi et al. ${ }^{0}$ reported that the seasonal blooms (summer in 1980, spring in 1981, and both in 1982) of $A$. tamarense were closely related to scallop toxicity. Kodama and Ogata ${ }^{4}$ indicated that $A$. tamarense was responsible for the high toxicity of scallop in spring blooms but not in autumn blooms, while the association of $\mathrm{A}$. catenella to shellfish toxicity was not clear in this region. Seven isolates of $A$. catenella from Tanabe Bay showed a higher proportion of $N$-sulfocarbamoyl toxins ( $79-95 \%$ ), including GTX5 and GTX6, and the toxin compositions were very similar to those of the isolates from the Seto Inland Sea except for containing NEO (Table 2). As shown in Fig. 1, toxin profiles of the isolates of A. catenella from Ofunato Bay clearly differed from those of the isolates from Tanabe Bay and the Seto Inland Sea, not only in lacking GTX1+ GTX4 and GTX6, but also in containing NEO to a higher proportion, although $A$. catenella from Ofunato Bay is completely identical to that from Tanabe Bay in the criteria of morphology, $\left.{ }^{10}\right)$ isozyme analysis, ${ }^{17}$ and monoclonal antibody. ${ }^{18}$ ) The same trend in toxin composition variation related to regional populations was documented on the isolates of northern Japan, ${ }^{7,253}$ North America, ${ }^{8-10}$ and widely separated geographical regions. ${ }^{11}$ ) Ofunato Bay and Tanabe Bay are geographically distant from each other (more than $1,000 \mathrm{~km}$ ), and Ofunato Bay belongs to the Oyashio, while Tanabe and the Seto Inland Sea belong to the Kuroshio. Considering these facts, it is probable that intraspecific indigenous populations have developed in each region.

\section{Acknowledgements}

The authors wish to thank Dr. T. Oshima (Tohoku University) for reference PSP toxins for HPLC calibration. This work was partly supported by a grant from Ministry of Agriculture, Fisheries, and Forestry of Japan.

\section{References}

1) Y. Shimizu: Dinoflagellate toxins, in "The Biology of Dinoflagellates", Vol. 21, (ed. by F. J. R. Taylor), Black well Scientifis, Oxford, 1987, pp. 282-315.
2) Y. Hashimoto, T, Noguchi, and R. Adachi: Occurrence of toxic bivalves in association with the bloom of Gonyaulax sp. in Owase Bay. Nippon Suisan Gakkaishi, 42, 671-676(1976)

3) Y. Oshima, Y. Shimizu, S. Nishio, and T. Okaichi: Identification of paralytic shellfish toxins in shellfish from Inland Sea. Nippon Suisan Gakkaishi, 44, 395 (1978).

4) T. Ogata, M. Kodama, Y. Fukuyo, T. Inoue, H. Kamiya, F. Matsuura, K. Sekiguchi, and S. Watanabe: The occurrence of Protogonyaulax spp. in Ofunato Bay, in association with the toxification of the scallop Patinofecten yessoonsis. Nippon Suisan Gakkaishi, 48, 563-566 (1982).

5) Y. Oshima, T. Yasumoto, M. Kodama, T, Ogata, Y. Fukuyo, and F. Matsuura: Features of paralytic shellfish poison occurring in Tohoku district. Nippon Suisan Gakkaishi, 48, 525-530 (1982).

6) K. Sekiguchi, N. Inoguchi, M. Shimizu, S. Saito, S. Watanabe, T. Ogata, M. Kodama, and Y. Fukuyo: Occurrence of Protogonyaulax tamarensis and shellfish toxicity in Ofunato Bay from 1980 1986, in "Red Tides" (ed. by T. Okaichi, D. M. Anderson, and T. Nemoto), Elsevier, New York, 1989. pp. $399-402$.

7) Y. Oshima, T. Hayakawa, M. Hashimoto, Y. Kotaki, and T, Yasumoto: Classification of Profogonyawhax tamarensis from North Japan into three strains by toxin composition. Nippon Suisan Gakkaishi, 48, 851-854 (1982).

8) M. I. Alam, C.P. Hsu, and Y. Shimizu: Comparison of toxins in three isolates of Gonyaulax tamarensis (Dinophyceae). J. Phycol., 15, 106-110 (1979).

9) S. Hall: Toxins and toxicity of Protogonyaulax from the northeast Pacific. Doctoral thesis, Univ. Alaska, Fairbanks, AK, 1982.

10) L. Maranda, D. M. Anderson, and Y. Shimizu: Comparison toxicity between populations of Gonyaulax tamarensis of eastern North American waters. Estuar. Cstl. Shelf. Sci. $21,401-410$ (1985).

11) A. E. Cembella, J. J. Sullivan, G. L. Boyer, F. J. R. Taylor, and R.J. Anderson: Variation in paralytic shellfish toxin composition within the Protogonyoulax ramarensis/catenella species complex: Red tide dinoflagellates. Biochem. Syst. Ecol., 15, 171-186 (1987).

12) Y. Oshima, K. Sugino, H. Itakura, M. Hirota, and T. Yasumoto: Comparative studies on paralytic shellfish toxin profile of dinoflagellates and bivalves, in "Toxic Marine Phytoplankton", (ed. by E, Graneli, B. Sundström, L. Edler, and D. M. Anderson), Elasevier, New York, 1990, pp. 391-396.

13) C.-H. Kim, Y. Sako, and Y. Ishida: Variation of toxin production and composition in axenic cultures of Alexandrium catenella and A. tamarense. Nippon Suisan Gakkaishi, 59, 633-639 (1993).

14) Y. Sako, C.-H. Kim, and Y. Ishida: Mendelian inheritance of paralytic shellfish poisoning toxin in the marine dinoflagellate Alexandrium catenella. Biosci. Biotech. Biochem., 56, 692-694 (1992)

15) Y. Oshima, K. Sugino, and T. Yasumoto: Latest advances in HPLC analysis of paralytic shellish toxins, in "Proceedings of the 7th International Symposium on Mycotoxins and Phycotoxins" (ed. by S. Natori, K. Hashimoto, and Y. Ueno), Elsevier, Amsterdam, 1989, pp. 319-326.

16) Y. Fukuyo, K. Yoshida, and H. Inoue: Protogonyaulax in Japanese coastal waters, in "Toxic Dinoflagellates" (ed. by D. M. Anderson, A. W. While, and D. G. Baden), Elsevier, New York, 1985, pp. 27-32.

17) Y. Sako, C.-H. Kim, H. Ninomiya, M. Adachi, and Y. Ishida: Isozyme and cross analysis of mating populations in the Alexandrium carenella/tamarense species complex, in "Toxic Marine Phytoplankton" (ed. by E. Graneli, S. Sundström, L. Edler, and D. M. Anderson), Elsevier, New York, 1990. pp. 320-323.

18) Y. Sako, M. Adachi and Y. Ishida: Preparation and characterization of monoclonal antibodies to Alexandrium species. in "Toxic Phytoplankton Blooms in the Sea" (ed. by T. J. Smayad and Y. Shimizu), Elservier, Amsterdam, 1993, in press. 
19) D. H. Turpin, P. E. R. Dobell, and F. J. R. Taylor: Sexuality and cyst formation in Pacific strains of the toxic dinoflagellate Gonyaulax tamarensis. J. Phycol., 14, 235-243 (1978).

20) D. M. Anderson: Effects of temperature conditioning on development and germination of Gonyaulax tamarensis (Dinophyceae) hypnozygotes. J. Phycol., 16, 166-172 (1980).

21) S, Yoshimatsu: Sexual reproduction of Protoganyaulax catenella in culture 1. Heterothallism. Bull. Plankton Soc. Japan, 28, 131-139 (1981).

22) D. M. Anderson: Toxin variability in Alexandrium species, in "Toxic Marine Phytoplankton", (ed. by .E. Graneli, S. Sundstrom, L. Edler, and D. M. Anderson), Elsevier, New York, 1990, pp. 41-51.
23) G. L. Boyer, J. J. Sullivan, T. J. Anderson, P. J. Harrison, and F.J.R. Taylor: Effects of nutrient limitation on toxin production and composition in the marine dinoflagellate Protogonyaulax tamarensis. Mar. Biol., 96, 123-128 (1987).

24) T. Ogata, T. Ishimaru, and M. Kodama: Effects of water temperature and light intensity on growth rate and toxicity change in Protogonyaulax tamarensis. Mar, Biol., 95, 217 220 (1987).

25) Y. Oshima and T. Yasumoto: Content of carbamoyl $N$ sulfated saxitoxin analogues in Protogonyaulax catenella from Japanese coastal waters. Bull. Mar, Sci, 37, 773-774 (1985). 